The Bangladesh Veterinarian (2013) 30(2) : 41 - 45

\title{
Comparative immunogenicity of fowl cholera vaccine in Jinding ducks
}

\author{
S Sultana, S Saha and MM Amin* \\ Department of Microbiology and Hygiene, Faculty of Veterinary Science, Bangladesh \\ Agricultural University, Mymensingh-2202, Bangladesh
}

\begin{abstract}
This study compared the immunogenicity of alum-precipitated formalin-killed fowl cholera vaccines (BAU-FCV and LRI-FCV) in Jinding ducks. The ducks were divided into three groups $(A=14, B=14, C=12)$. Group A was inoculated with BAU- FCV $0.5 \mathrm{~mL}$ and group B with LRI- FCV $1.0 \mathrm{~mL}$ intramuscularly (im) at the age of six weeks and group C served as unvaccinated control. Booster vaccination was administered similarly at 11 weeks of age in groups A and B. Challenge infection was given to all birds two weeks after booster vaccination. Passive Haemagglutination Assay (PHA) antibody titres in group A were $59.4 \pm 4.621$ days after primary vaccination, $137.1 \pm 21.815$ days after booster vaccination, $100.6 \pm 12.921$ days after booster vaccination, and $256.0 \pm 48.415$ days after challenge. In group B, titres were $50.3 \pm 6.5,118.9 \pm 9.1,91.4 \pm 12.9,237.7 \pm 51.7$, respectively, whereas titres in group $C$ remained at $\leq 4.0 \pm 0.0$. The antibody titres were insignificant when compared between pre-vaccination and 21 days after primary vaccination in both vaccinated groups (A and B). PHA antibody titres of groups A were significantly $(\mathrm{P}<0.0001)$ increased at 15 days after booster and in case of group $B$ the antibody titres were insignificant. At 15 days after challenge the antibody titres were highly significant in both groups (A and B). There was no significant difference between the two vaccinated groups. Following challenge infection with virulent Pasteurella multocida $88.9 \%$ of birds vaccinated with BAU-FCV, and $77.8 \%$ of birds vaccinated with LRI-FCV survived, while all unvaccinated birds died. Both vaccines were safe and effective. (Bangl. vet. 2013. Vol. 30, No. 2, 41 - 45)
\end{abstract}

\section{Introduction}

Ducks comprise about $10 \%$ of the total poultry population and occupy second place to chicken in the production of table eggs in Bangladesh (Khan et al., 1999). Diseases constitute the major constraints causing economic loss (Das et al., 2005). Fowl cholera is a major threat to poultry industry. This is caused by Pasteurella multocida and occurs sporadically or enzootically all over Bangladesh causing 25\% to 35\% mortality in chickens and ducks (Choudhury et al., 1985). Baki et al. (1991) observed that $11 \%$ of mortality of domestic ducks was due to fowl cholera. In order to control it, strict biosecurity and vaccination are essential. Vaccines are produced by Livestock Research Institute (LRI) and Bangladesh Agricultural University (BAU) to control fowl cholera in chickens and ducks. Field studies on such vaccines have been reported (Islam et al., 2004; Sukul et al., 2008; Rana et al., 2010). Jinding ducks were immunized by LRI-FCV subcutaneously (sc) and BAU-FCV intramuscularly (im), (Islam et al.,

\footnotetext{
*Corresponding author:- E-mail: maminbau@gmail.com
} 
2004).

This study was conducted to evaluate the humoral immune response in Jinding ducks following im vaccination with Fowl Cholera Vaccine (FCV) prepared by Bangladesh Agricultural University (BAU), Mymensingh and Livestock Research Institute (LRI), Mohakhali, Dhaka.

\section{Materials and Methods}

Experimental ducks

A total of 40 day-old ducklings of either sex of Jinding breed were collected from a hatchery at Brahmanbari. The birds were reared in a small shed (Huque, 1991) with biosecurity and were divided into three groups, A, B and C consisting of 14, 14 and 12 ducks, respectively.

Immunization of ducks

Birds of group A were vaccinated with $0.5 \mathrm{~mL}\left(1.75 \times 10^{8} \mathrm{CFU} / \mathrm{mL}\right)$ BAU-FCV, group $B$ with $1 \mathrm{~mL}$ LRI-FCV and group $\mathrm{C}$ were unvaccinated controls. Booster dose was provided using same dose and route five weeks after primary vaccination.

Collection of blood and preparation of sera

Blood serum was collected as described by Siddique et al. (1997). About three $\mathrm{mL}$ of blood without anticoagulant was collected from the right wing vein of all ducks and the syringes were held in slanted position and blood was allowed to clot at room temperature for an hour; clots were detached from the wall of the syringe by pressing the piston and were kept overnight at $4^{\circ} \mathrm{C}$ for separation of the serum. Then serum was carefully removed and centrifuged at $2000 \mathrm{rpm}$ for 10 minutes and stored at $-20^{\circ} \mathrm{C}$.

Determination of Passive Haemagglutination Assay (PHA) titres

The antibody titres were determined by PHA as described by Tripathy et al. (1970).

\section{Challenge to the experimental ducks}

After 28 days of booster immunization, all ducks were challenged with virulent field isolate of P. multocida, $10 \mathrm{LD}_{50}$ of mice $\left(0.25 \mathrm{~mL}\right.$ containing $\left.5.7 \times 10^{9} \mathrm{CFU} / \mathrm{mL}\right)$ injected into thigh muscle. These were observed daily at three-hour intervals for ten days for any clinical signs. In case of fatality post-mortem examinations were performed. For re-isolation of $P$. multocida, swabs from affected tissues were taken from ducks that died and streaked on to blood agar plates. The plates were examined after $24-48$ hours of incubation at $37^{\circ} \mathrm{C}$ (Matsumoto and Helfer, 1978) and positive cases were further

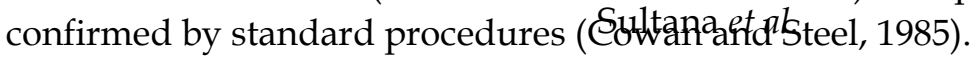


Statistical analyses were performed using SAS (2008) statistical package programme to evaluate differences in PHA titre between the three groups of ducks, and the survival rates were evaluated using Mantel-Cox log rank test. A P value of $<0.001$ was considered significant.

\section{Results and Discussions}

Antibody titres were calculated and presented as Mean \pm Standard error. The prevaccination PHA titres of sera samples of all ducks were a mean of $<4.0 \pm 0.0$, in agreement with Mondal et al. (1988). The mean antibody titre of group A was $59.4 \pm$ 4.6, 21 days after primary vaccination, $137.1 \pm 21.815$ days after booster vaccination, $100.6 \pm 12.928$ days after booster vaccination, and $256.0 \pm 48.4$ at 15 days after challenge. In group B titres were $50.3 \pm 6.5,118.9 \pm 9.1,91.4 \pm 12.9,237.7 \pm 51.7$, respectively.

Table 1. Mean PHA titres with standard error of sera of ducks vaccinated with BAUFCV and LRI-FCV. Ducks were immunized at 6 weeks of age and boosted at 11 weeks of age im $0.5 \mathrm{~mL} /$ duck $\left(1.75 \times 10^{8} \mathrm{CFU} / \mathrm{mL}\right)$ in group A and @ 1 $\mathrm{mL} /$ duck in group B. Serum was obtained at 6, 9, 13, 15 and 17 weeks of age. Serum antibody titre against vaccination was determined by PHA test. Means bearing dissimilar superscript in a row differ significantly $(\mathrm{P}<0.0001)$.

\begin{tabular}{l|c|c|c|c|c|c|c}
\hline Groups & Vaccines & $\begin{array}{c}\text { Dose and } \\
\text { route }\end{array}$ & $\begin{array}{c}\text { Pre- } \\
\text { immuniza- } \\
\text { tion }\end{array}$ & & \multicolumn{2}{|c|}{$\begin{array}{c}\text { Post-immunization PHA titres } \\
\text { Post- } \\
\text { primary }\end{array}$} & \multicolumn{2}{|c|}{$\begin{array}{c}\text { Post- } \\
\text { challenge }\end{array}$} \\
\cline { 5 - 7 } & & & 21 days & 15 days & 28 days & 15 days \\
\hline $\mathrm{A}$ & BAU-FCV & $0.5 \mathrm{~mL} \mathrm{im}$ & $\leq 4.0 \pm 0.0^{\mathrm{d}}$ & $59.4 \pm 4.6^{\mathrm{cd}}$ & $137.1 \pm 21.8^{\mathrm{b}}$ & $100.6 \pm 12.9^{\mathrm{bc}}$ & $256.0 \pm 48.4^{\mathrm{a}}$ \\
$\mathrm{B}$ & LRI-FCV & $1 \mathrm{~mL} \mathrm{im}$ & $\leq 4.0 \pm 0.0 \mathrm{c}$ & $50.3 \pm 6.5^{\mathrm{bc}}$ & $118.9 \pm 9.1^{\mathrm{b}}$ & $91.4 \pm 12.9 \mathrm{~b}$ & $237.7 \pm 51.7 \mathrm{a}$ \\
$\mathrm{C}$ & Control & - & $\leq 4.0 \pm 0.0$ & $\leq 4.0 \pm 0.0$ & $\leq 4.0 \pm 0.0$ & $\leq 4.0 \pm 0.0$ & $\leq 4.0 \pm 0.0$ \\
\hline
\end{tabular}

The antibody titres were insignificant when compared between pre-vaccination and 21 days after primary vaccination in both vaccinated groups. When compared between 21 days of primary vaccination and 15 days of booster vaccination the antibody titres were highly significant $(\mathrm{P}<0.0001)$ in group $\mathrm{A}$ and in case of group $\mathrm{B}$ the antibody titres were insignificant. The antibody titres were insignificant when compared between 15 days of booster vaccination and 28 days of booster vaccination in both groups. However, the antibody titres were highly significant $(\mathrm{P}<0.0001)$ when compared between 28 days of booster vaccination and 15 days following challenge but when compared between two groups (A and B) there was no significant variation.

At 21 days after primary vaccination the antibody titres were significantly increased $(\mathrm{P}<0.01)$ in both vaccinated groups, but there was no significant difference between these groups. At 15 days after booster vaccination, the antibody titres in groups $\mathrm{A}$ and $B$ had increased significantly $(\mathrm{P}<0.01)$ compared with 21 days after primary vaccination, but was not significantly different compared with that at 15 and 28 days after booster vaccination. However, the antibody titres were significant $(\mathrm{P}<0.01)$ when compared with those obtained at 28 days of booster vaccination and also those 
obtained at 15 days following challenge but when compared between two groups, there was no significant variation.

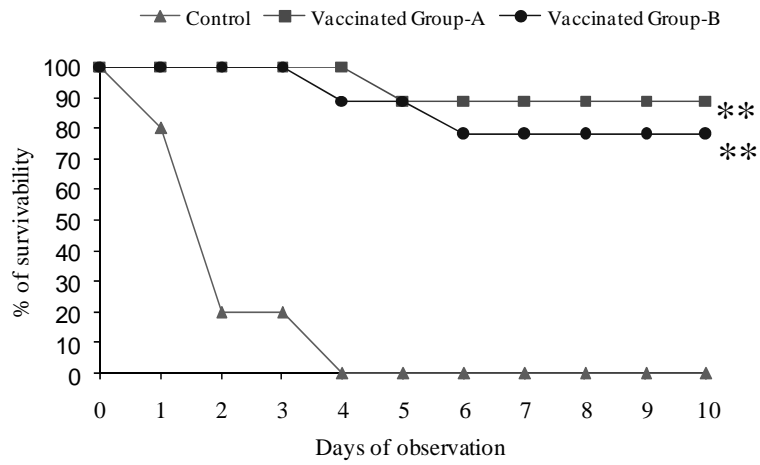

Fig. 1. Survival of ducks following challenge with virulent field isolate of Pasteurella multocida in Group A (BAU-FCV), Group B (LRI-FCV) and Group C (Control). ** $(\mathrm{P}<0.01)$ by Mantel-cox log rank test when compared with control group.

After challenge with a virulent isolate of $P$. multocida $88.9 \%$ of ducks immunized with BAU-FCV, and $77.8 \%$ immunized with LRI-FCV survived, whereas none of the unvaccinated control ducks survived. Islam et al. (2004) immunized ducks with LRIFCV and BAU-FCV and showed 95\% and 90\% survived challenge infection three weeks after vaccination. The present results support the report of Ali and Sorwar (1975); Khan et al. (1994) who recorded 80\% protection of chickens vaccinated with LRI-FCV.

\section{Conclusions}

It may be concluded that both the fowl cholera vaccines were safe and effective providing satisfactory protection against duck cholera in Jinding ducks.

\section{References}

Ali MI, Sorwar MG 1975: Studies on duck cholera vaccine. Bangladesh Veterinary Journal 9 29-30.

Baki MA, Islam MR, Das PM, Karmaker PK and Mondal MMH 1991: Pathology of duck cholera in natural and experimental infection. Bangladesh Journal of Microbiology 8 1-4.

Choudhury KA, Amin MM, Rahman A and Ali MR 1985: Investigation of natural outbreak of fowl cholera. Bangladesh Veterinary Journal 19 49-56.

Cowan ST, Steel KS 1985: Manual for Identification of Bacteria, $2^{\text {nd }}$ edn, Cambridge University Press, Cambridge, London.

Das PM, Rajib DMM, Noor M and Islam MR 2005: Retrospective analysis on tile proportional incidence of poultry diseases in greater Mymensingh district of Bangladesh. In proceeding of $4^{\text {th }}$ International Poultry show and seminar from

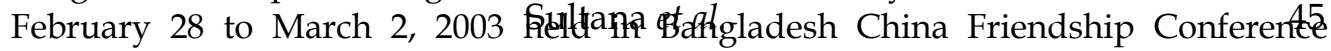
Centre, Agargaon, Dhaka pp. 35-39.

Huque QME 1991: Duck production system in Bangladesh. Asian Livestock 16 18-23. 
Islam MA, Samad MA, Rahman MB 2004: Evaluation of alum precipitated formalin killed fowl cholera vaccines with their immunologic responses in ducks. International Journal of Poultry Science 3 140-143.

Khan MAHNA, PM Das, KA Chowdhury, MR Islam 1994: Efficacy of alum precipitated fowl cholera vaccine in chicken. Bangladesh Veterinary Journal 28 25-30.

Khan MK, Ali A, Bhulyan AK 1999: Economic traits of Deshi males with Isa brown females under farm and rural conditions. Bangladesh Journal of Animal Sciences 289.

Matsumoto M, Helfer DH 1978: A bacterin against fowl cholera in turkeys: protective quality of various preparations originated from broth cultures. Avian Diseases 21 382393.

Mondal SK, Choudhury KA, Amin MM, Rahman MM, Sarker AJ 1988: Immune response in chickens induced by Alum precipitated fowl cholera vaccine: Humoral immune response. Bangladesh Veterinary Journal 22 63-69.

Rana M, Hossain MT, Islam MA, Rahman MM, Alam MK, Dutta UK 2010: Comparative immunogenicity study in ducks of different breeds available at coastal regions of Bangladesh against duck plague and duck cholera vaccines. International Journal of Bioresearch 2 23-27.

SAS 2008 SAS User`s Guide, Version 8 Edition, Cary, NC, USA: Statistical Analysis System Institute. Inc.

Siddique AB, Rahman MB, Amin MM, Rahman MM 1997: Antibody titres in chicks following pigeon poxvirus inoculation. The Bangladesh Veterinarian 14 12-14.

Sukul M, Khan MSR, Rahman MT, Begum K 2008: Immunogenicity of capsular extract prepared from a local duck isolate of P. multocida. Bangladesh Journal of Veterinary Medicine 6 19-22.

Tripathy DN, Hanson LE, Myers WL 1970: Passive haemagglutination test with fowl pox virus. Avian Diseases 14 29-38.

Matsumoto M, Helfer DH 1978: A bacterin against fowl cholera in turkeys: protective quality of various preparations originated from broth cultures. Avian Diseases 21 382-393.

Mondal SK, Choudhury KA, Amin MM, Rahman MM, Sarker AJ 1988: Immune response in chickens induced by Alum precipitated fowl cholera vaccine: Humoral immune response. Bangladesh Veterinary Journal 22 63-69.

Rana M, Hossain MT, Islam MA, Rahman MM, Alam MK, Dutta UK 2010: Comparative immunogenicity study in ducks of different breeds available at coastal regions of Bangladesh against duck plague and duck cholera vaccines. International Journal of Bioresearch 2 23-27.

SAS 2008 SAS User`s Guide, Version 8 Edition, Cary, NC, USA: Statistical Analysis System Institute. Inc.

Siddique AB, Rahman MB, Amin MM, Rahman MM 1997: Antibody titres in chicks following pigeon poxvirus inoculation. The Bangladesh Veterinarian 14 12-14.

Sukul M, Khan MSR, Rahman MT, Begum K 2008: Immunogenicity of capsular extract prepared from a local duck isolate of P. multocida. Bangladesh Journal of Veterinary Medicine 6 19-22.

Tripathy DN, Hanson LE, Myers WL 1970: Passive haemagglutination test with fowl pox virus. Avian Diseases 14 29-38. 